\title{
Influence of Sea Surface Temperature on the Gonadal development of Sea urchin Temnopleurus toreumaticus from the Gulf of Mannar, South East Coast of India
}

\author{
RAJU SARAVANAN ${ }^{1 *}$, PAULRAJ JAWAHAR ${ }^{2}$, THOMMAI FRANCIS ${ }^{2}$, \\ BABOONSUNDARAM AHILAN ${ }^{2}$ and RAJAGOPAL SANTHAKUMAR ${ }^{2}$
}

${ }^{1}$ Regional Centre of Central Marine Fisheries Research Institute, Mandapam Camp, Marine Fisheries Post -623 520, Ramanathapuram Dt., Tamil Nadu, India. ${ }^{2}$ Fisheries College and Research Institute, Thoothukkudi - 628 008, Tamil Nadu, India.

http://dx.doi.org/10.12944/CWE.11.1.17

(Received: February 10, 2016; Accepted: March 01, 2016)

\begin{abstract}
This study was conducted for a 20 months period from October 2013 to May 2015 in Gulf of Mannar, south east coast of India. During the investigation the abiotic factors viz., Sea surface temperature (SST), Daylight photoperiod and atmospheric temperature data were collected from International comprehensive Ocean Atmospheric Database (ICOADS) and the reproductive cycle of the sea urchin was studied from the monthly sampling of sea urchin collected from Vedalai landing centre in Gulf of Mannar. The gonads were studied to calculate Gonad index as well histological to categories them into four different stages of the development and this data was compared with abiotic factors to study the influence of it on the reproductive behaviour of sea urchin. The data were analyzed statistically through Pearson correlation and it was found negative between mean monthly gonad index and day length photoperiod, as well as with SST. This clearly indicates that the gonadal development in sea urchin is very much influenced by these two abiotic factors; however other nutritional factors might play greater role in the development gonad.
\end{abstract}

Key words: Sea urchin, Echinoid, Temnopleurus toreumaticus, Gulf of Mannar, Abiotic factors, Photoperiod, Sea Surface Temperature (SST), Gonad index, Gonadal development

\section{INTRODUCTION}

Many countries around the world consume the gonad(roe) of the sea urchin as a delicacy food. Japan and France are the two main countries which consume the maximum global production of sea urchin roe from the wild as well as aquaculture. A number of countries have developed the mariculture technologies for growing sea urchin to cater to this global demand using their local species. Among the two types of sea urchin Viz., Regular and Irregular urchins, the regular urchins are used as food. In the
Gulf of Mannar, the diversity of regular sea urchin diversity stands at 24 . At certain pockets of the east and west coast of India fisher folk consume the gonads of sea urchin, other than this no organized trading or cultivation is being carried out. This is mainly due to the lack of knowledge on the biology of the regular sea urchin species available in India. Hence this study aimed at understanding the gonadal development process with respect to the abiotic factors viz., SST and Photoperiod in the Gulf of Mannar, which boast a diverse variety of sea urchin fauna. 


\section{MATERIALS AND METHODS}

The present study was conducted along the Mandapam coast of Gulf of Mannar and monthly sampling was carried out from Vedalai landing centre, where bottom set gill net was operational. 30 individuals of sea urchin species Temnopleurus toreumaticus have been routinely collected for twenty months since October 2013 till May 2015 to study the gonado somatic index. The collected sea urchin were transported to the Central Marine Fisheries Research Institute(CMFRI), Mandapam laboratory in sea water. The total weight of the sea urchin was measured to the nearest $0.001 \mathrm{~g}$, only after draining water from its test. The sea urchin use water to maintain hydrostatic pressure inside test, hence the drained weight is used. The sea urchin test was opened using a scalpel and the five gonads are removed one after another with care and weighed. This gonad weight is compared with the total drained weight of the whole urchin to arrive at the gonadosomatic index (GSI) (Muthiga and Jaccarini, 2005; Vaitilingon et al., 2005) as follows;

GSI $(\%)=$ Wet weight of gonad $(g) /$ Total wet weight of sea urchin $(\mathrm{g}) \times 100$

The gonadosomatic index (GSI), which measures the relative changes in weight in the gonads over time, was used on urchins as early as

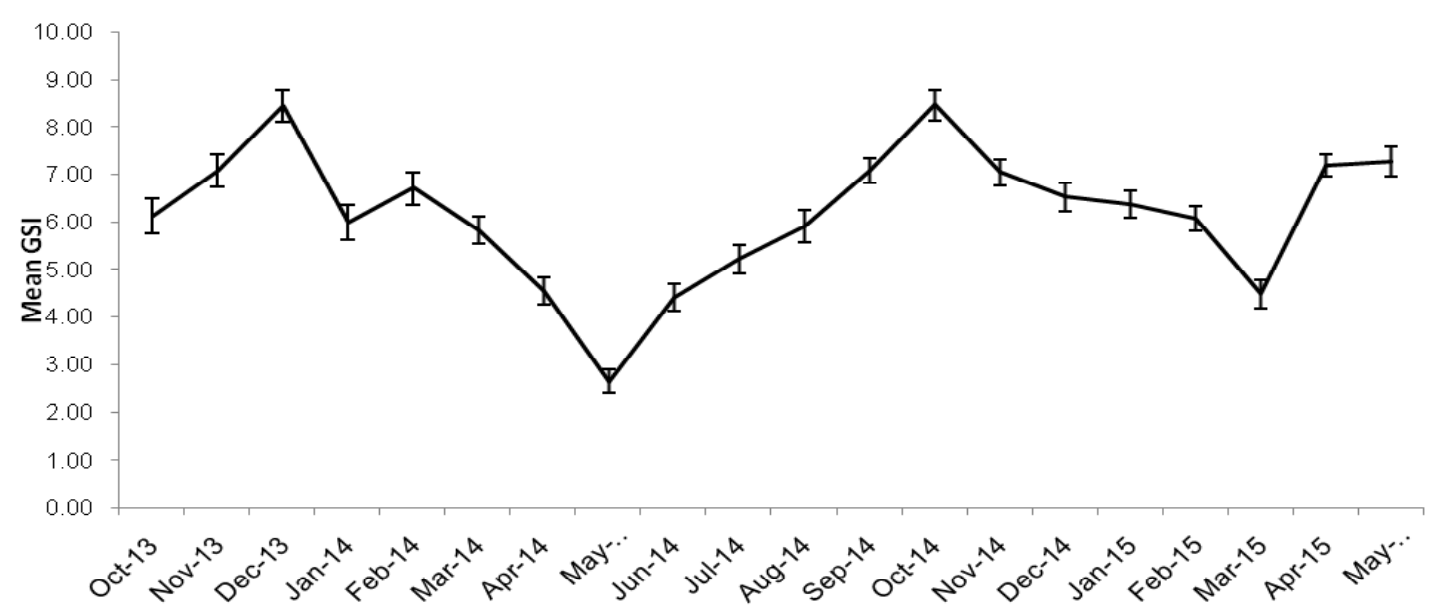

Fig.1: Temporal variations in mean Gonad index of T. toreumaticus in Gulf of Mannar

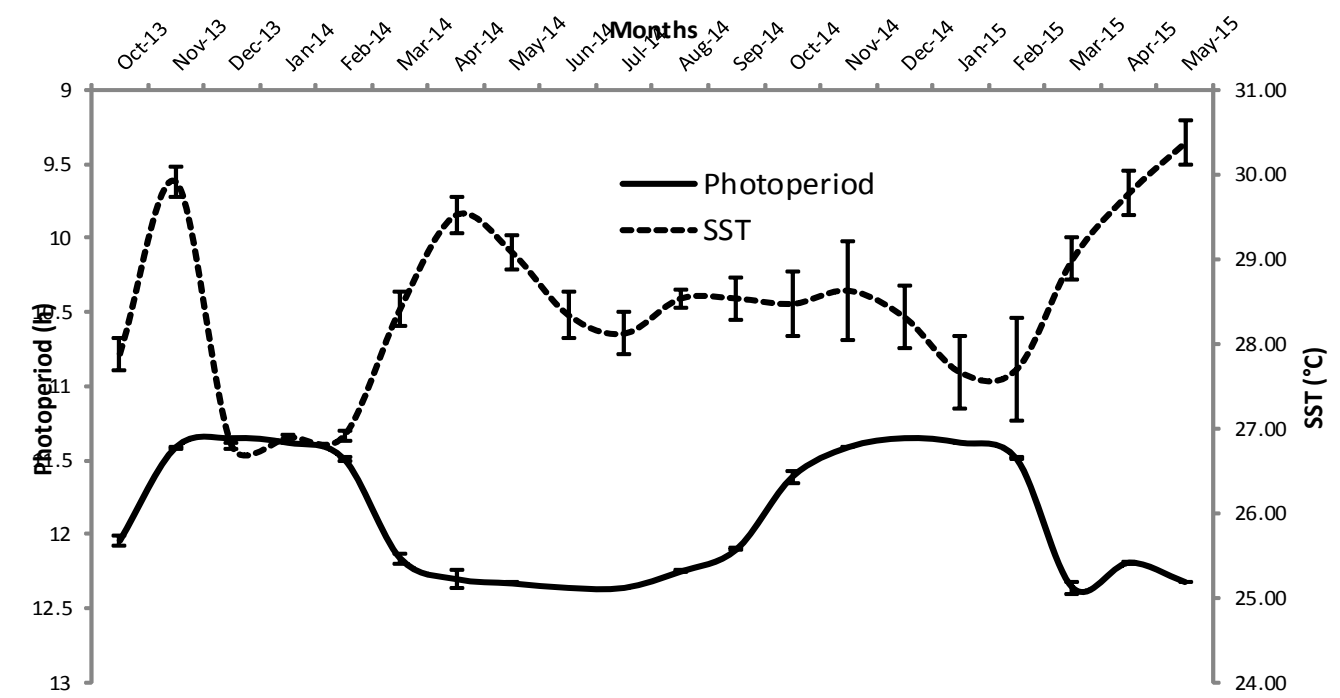

Fig. 2: Comparison of Photoperiod and SST variations in Gulf of Mannar during the study period 
Table 1: Correlations between SST versus Mean GSI

\begin{tabular}{llcc}
\hline & & SST & $\begin{array}{c}\text { Mean } \\
\text { GSITT }\end{array}$ \\
\hline SST & Pearson Correlation & 1 & -.319 \\
& Sig. (2-tailed) & & .170 \\
& N & 20 & 20 \\
Mean & Pearson Correlation & -.319 & 1 \\
GSITT & Sig. (2-tailed) & .170 & \\
& $\mathrm{~N}$ & 20 & 20 \\
\hline
\end{tabular}

1934 (Moore 1934), and is based on the assumption that maturation and breeding coincide with maximum gonad weight. A total of 600 individuals of sea urchin Temnopleurus toreumaticus were collected during 20 month period from October 2013 to May 2015. Differences in mean GSI were evaluated following the methods of Wangensteen et al., (2013).

The data on the Sea surface temperature and atmospheric temperature was obtained from the International Comprehensive Ocean-Atmosphere Data Set (ICOADS) Release 2.5(http://rda.ucar.edu/ datasets/ds540.0/) for the period of 20 months since October 2013 to May 2015. The day length photo

Table 2: Correlations between Photoperiod versus Mean GSI

\begin{tabular}{llcc}
\hline & & Photoperiod & MeanGSITT \\
\hline \multirow{2}{*}{ Photoperiod } & Pearson Correlation & 1 & -.400 \\
& Sig. (2-tailed) & & .081 \\
& N & 20 & 20 \\
Mean GSITT & Pearson Correlation & -.400 & 1 \\
& Sig. (2-tailed) & .081 & \\
& N & 20 & 20 \\
\hline
\end{tabular}

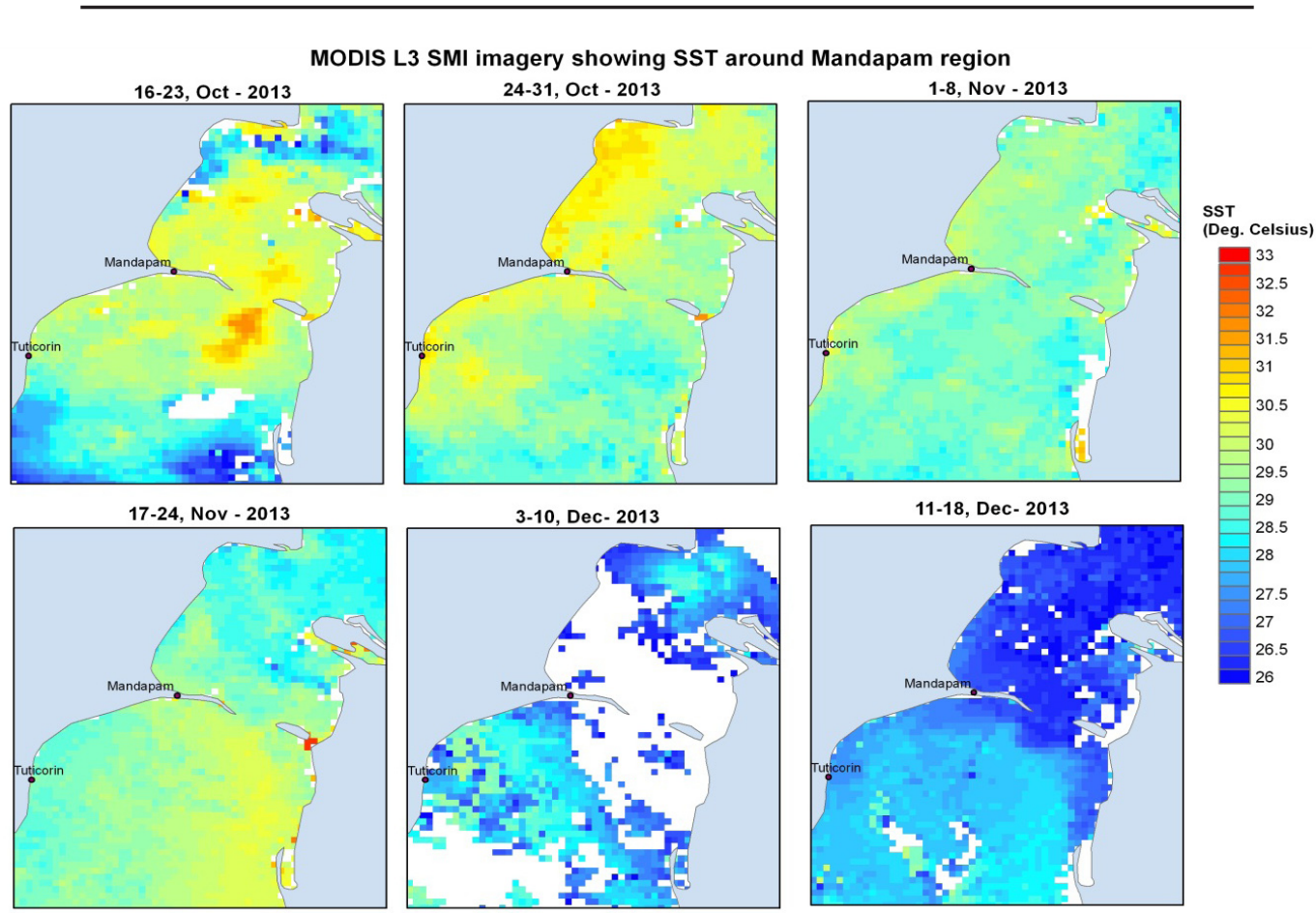

Fig. 3: SST Map of Gulf of Mannar and Palk bay during October to December 2013 


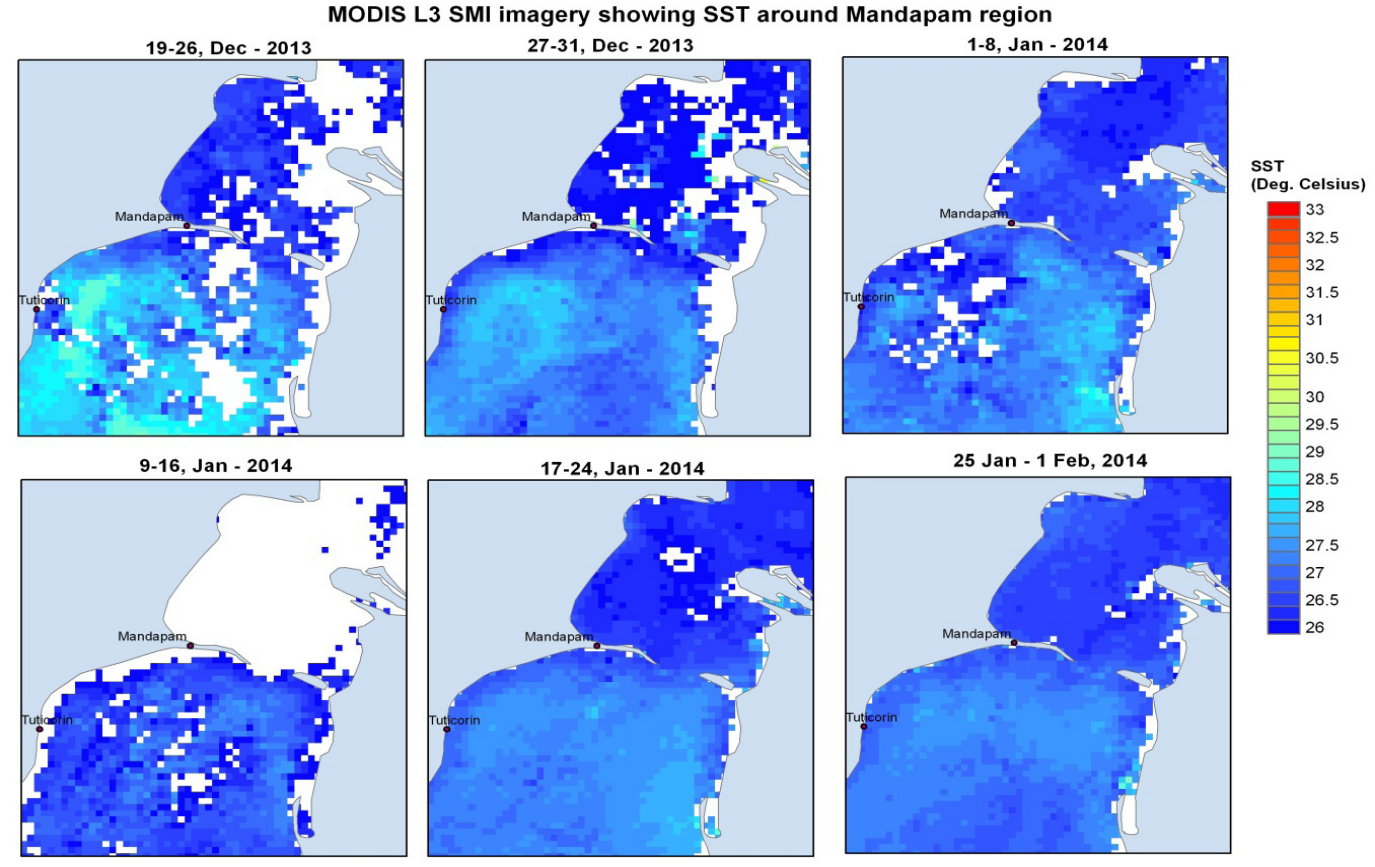

Fig. 4: SST Map of Gulf of Mannar and Palk bay during December 2013 to February 2014

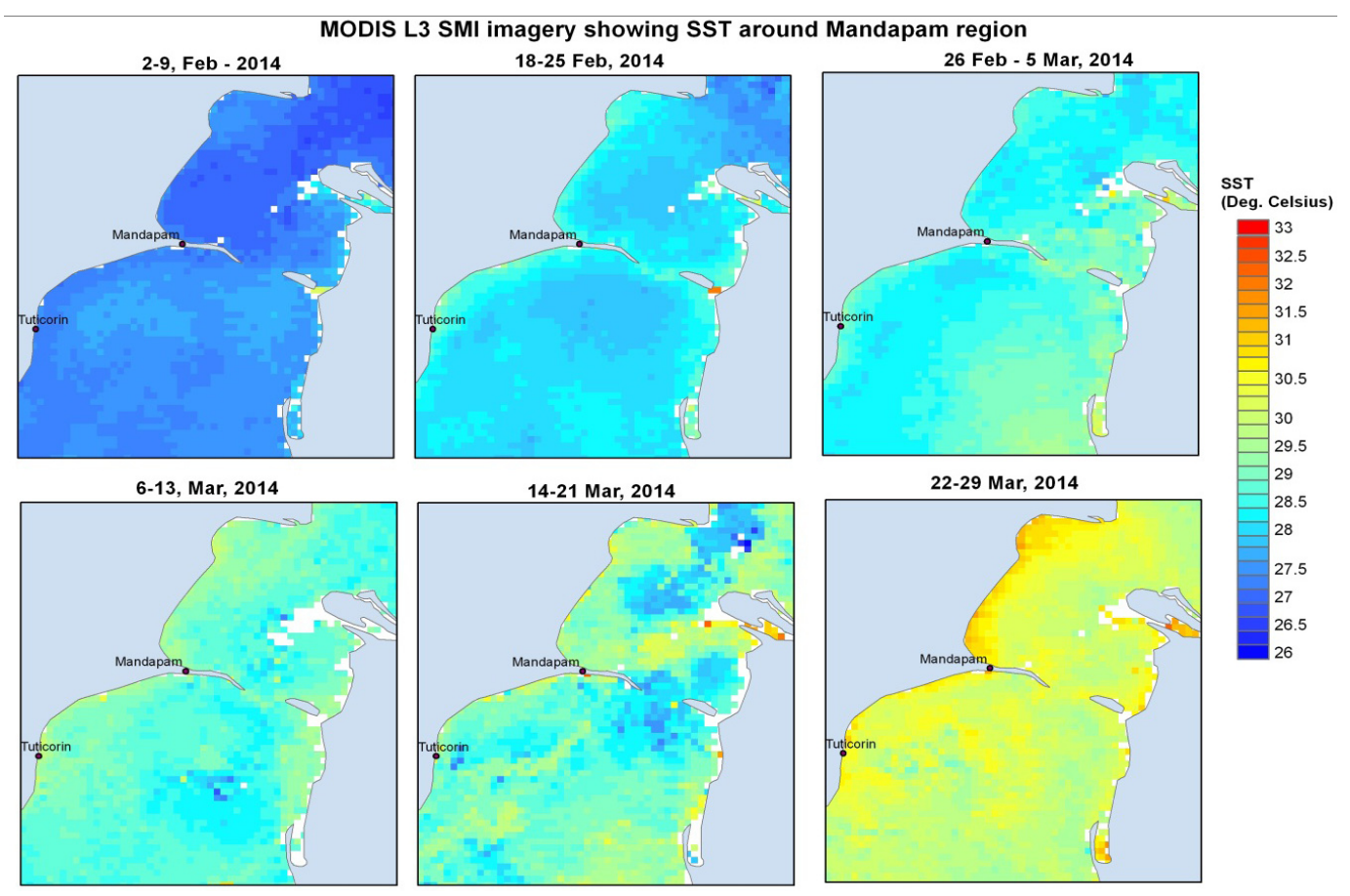

Fig. 5: SST Map of Gulf of Mannar and Palk bay during February 2014 to March 2014 


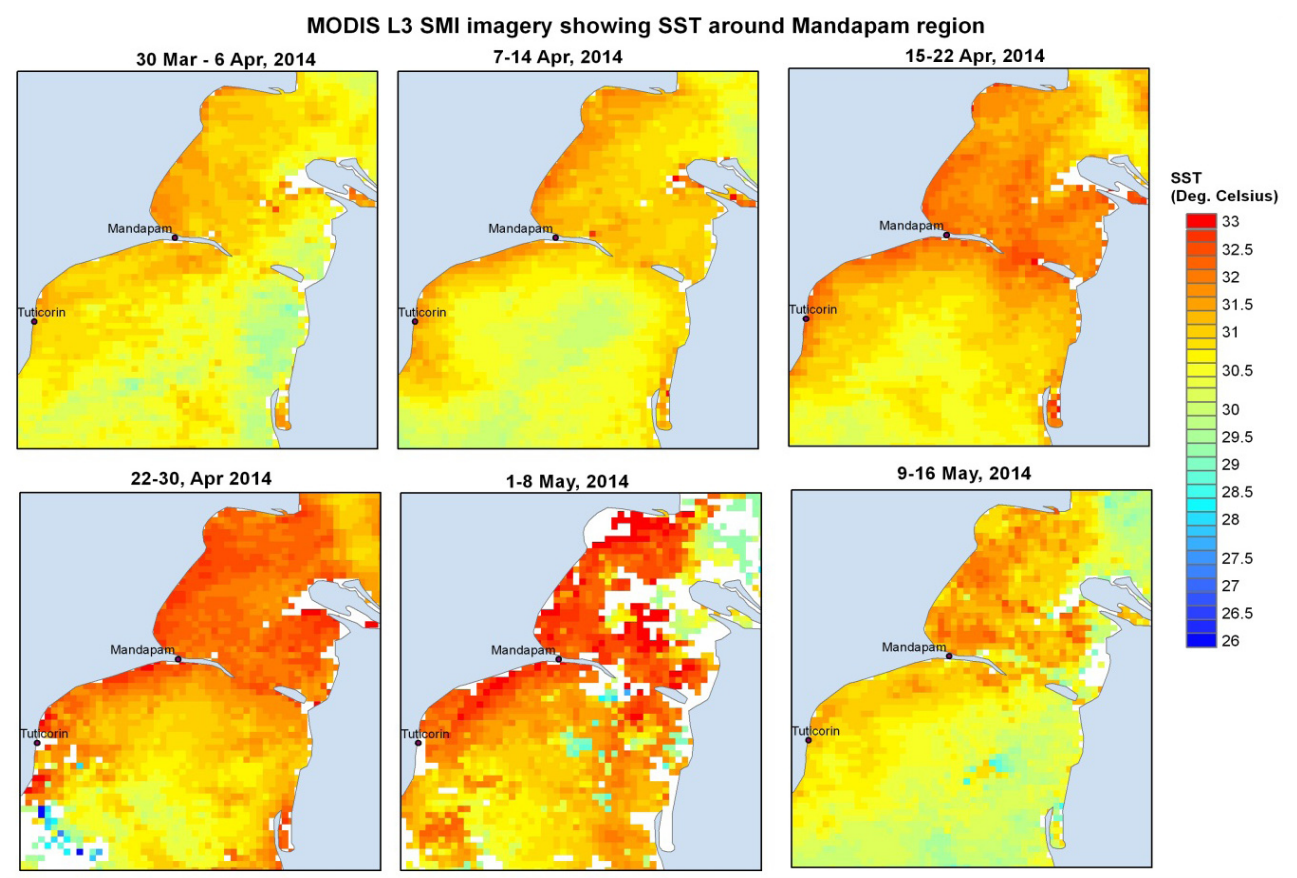

Fig. 6: SST Map of Gulf of Mannar and Palk bay during March 2014 to May 2014

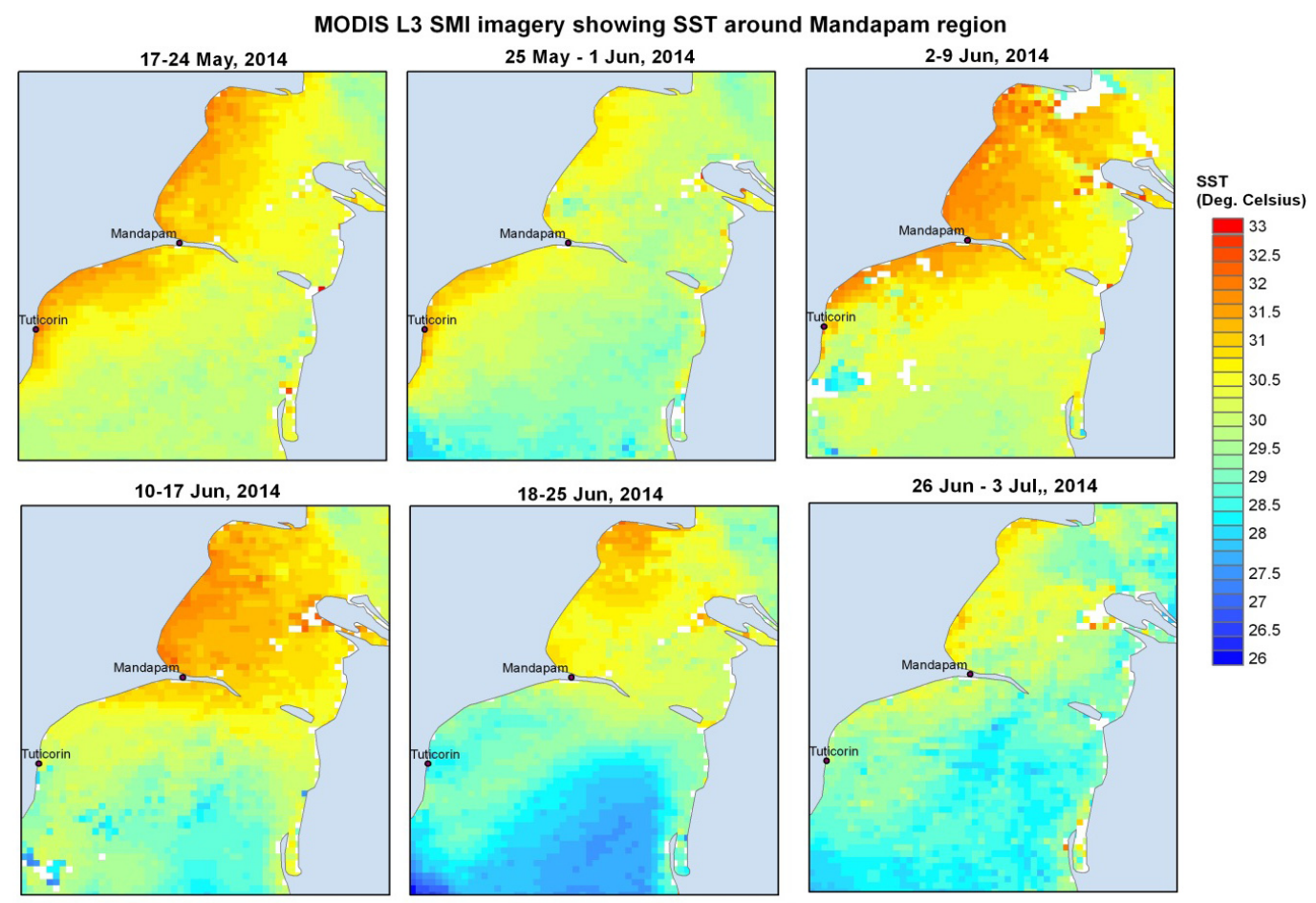

Fig. 7: SST Map of Gulf of Mannar and Palk bay during May 2014 to June 2014 


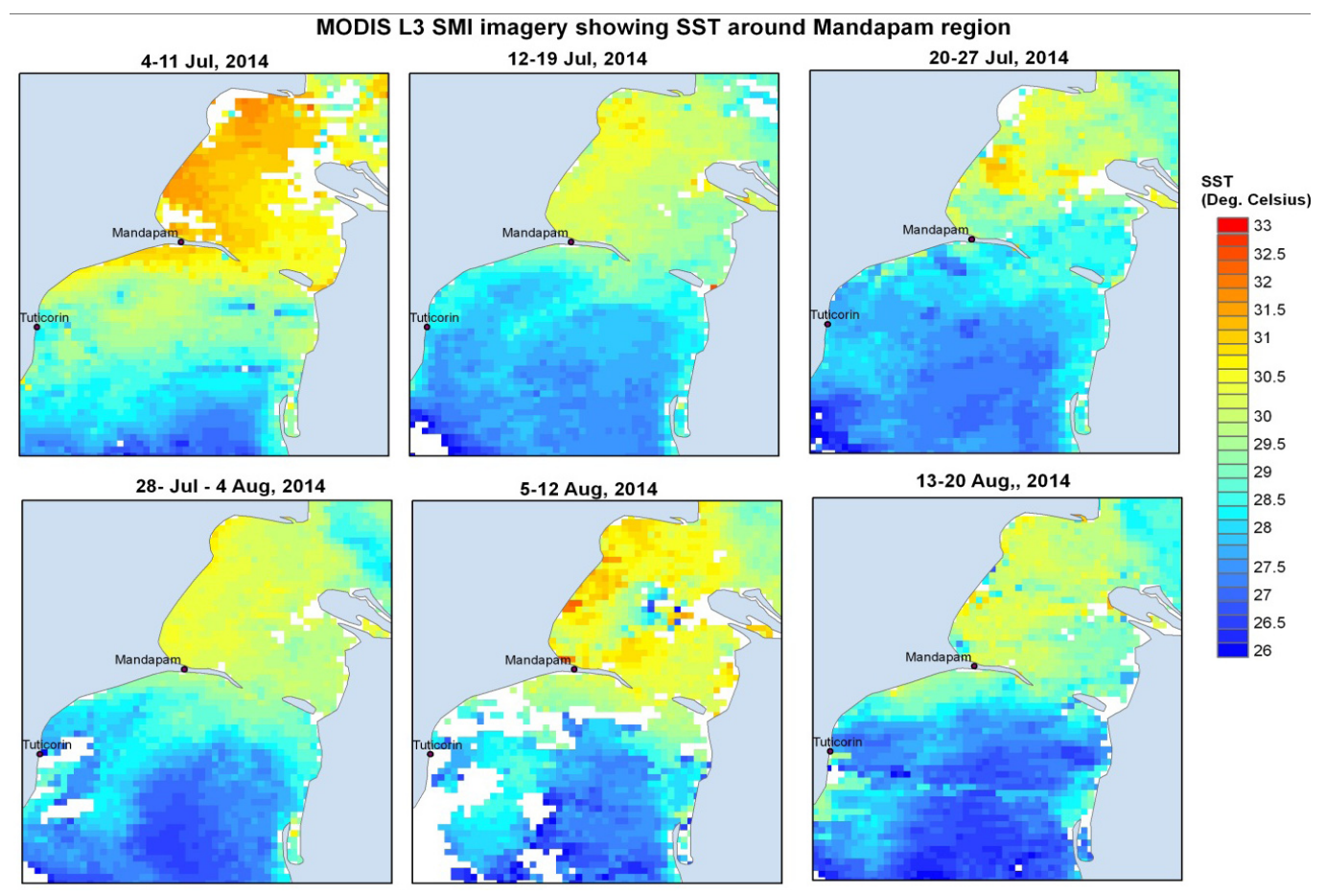

Fig. 8: SST Map of Gulf of Mannar and Palk bay during July 2014 to August 2014

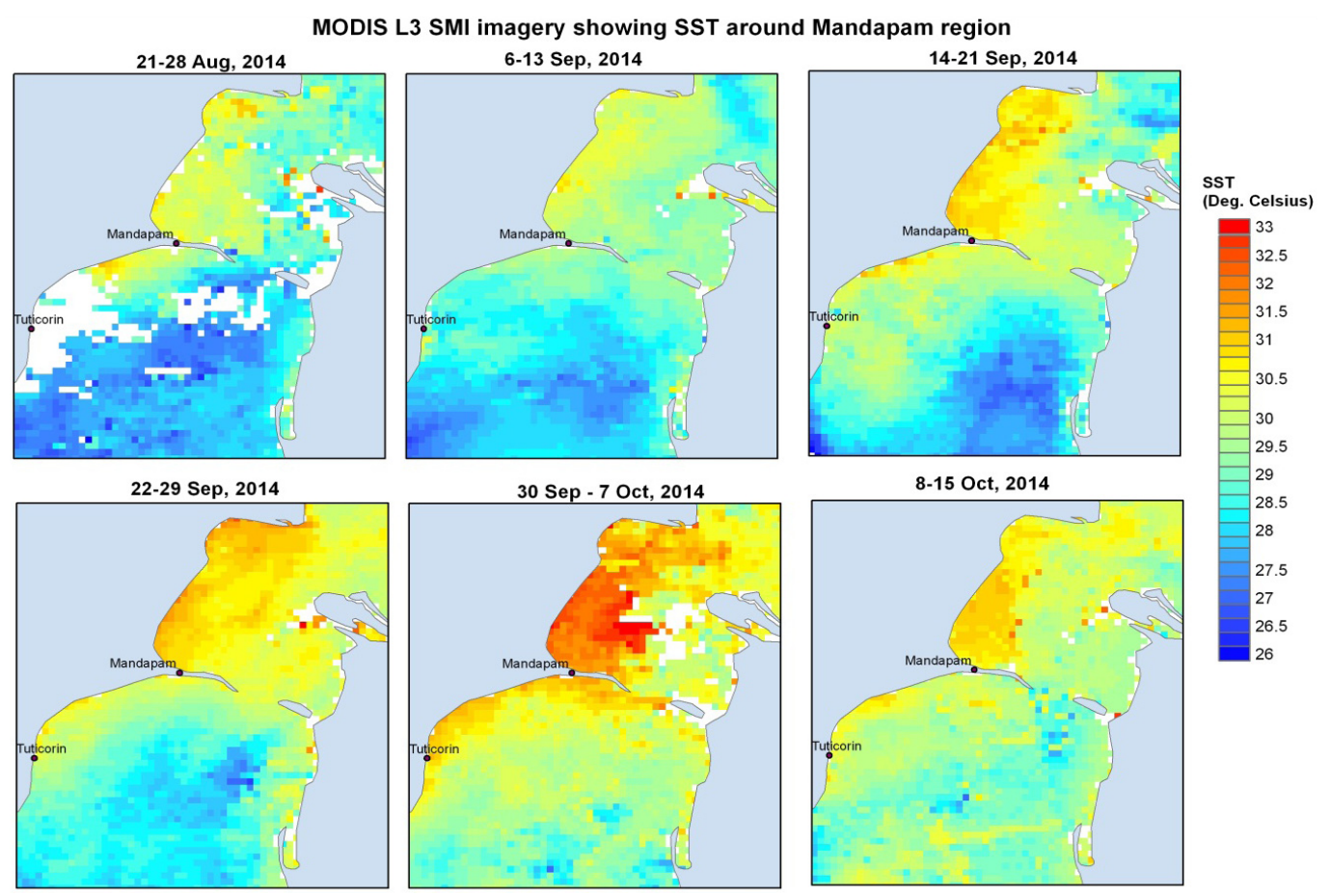

Fig. 9: SST Map of Gulf of Mannar and Palk bay during August 2014 to October 2014 
MODIS L3 Sea Surface Temperature Map of Mandapam region Sep 2014 to Jan 2015

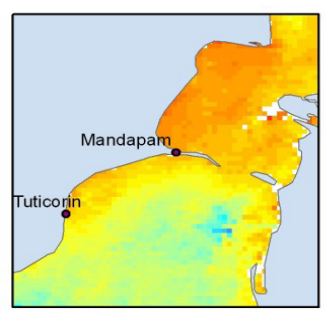

22-29 Sep 2014

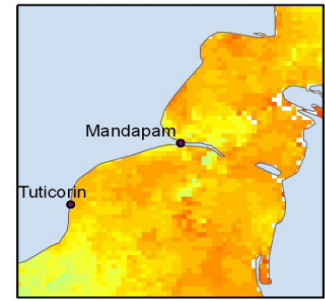

$24-31$ Oct 2014

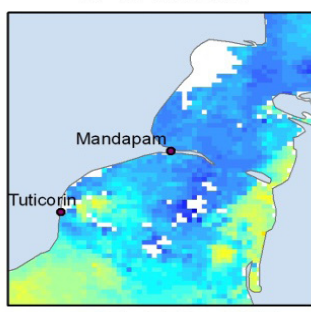

27 - 31 Dec 2014

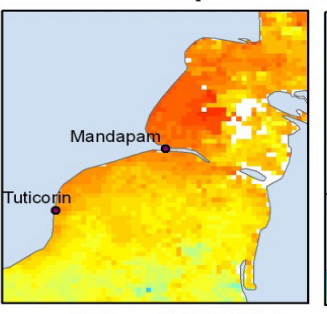

30 Sep - 7 Oct 2014

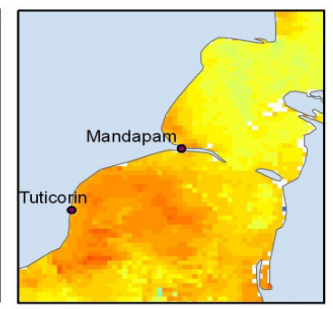

$1-8$ Nov 2014

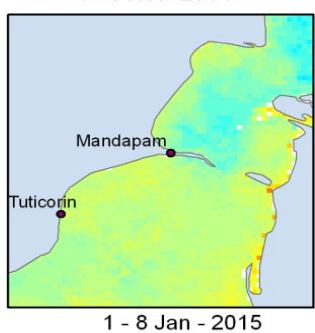

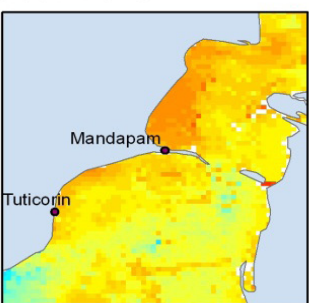

8 - 15 Oct 2014

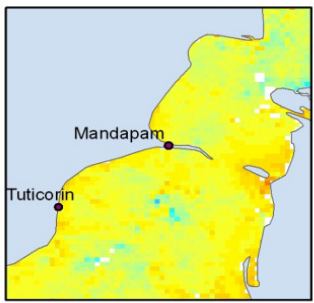

$9-16$ Nov 2014

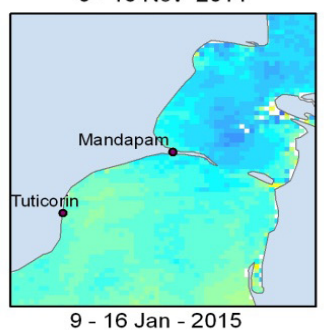

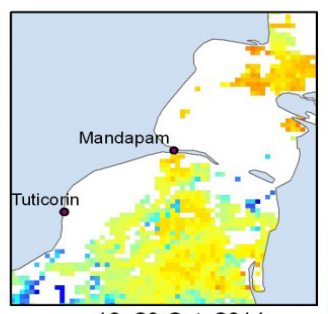

$16-23$ Oct 2014

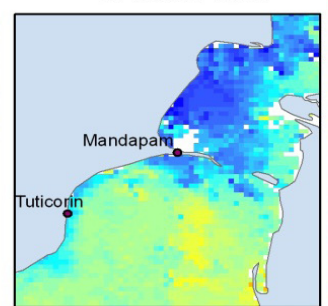

$3-10$ Dec 2014

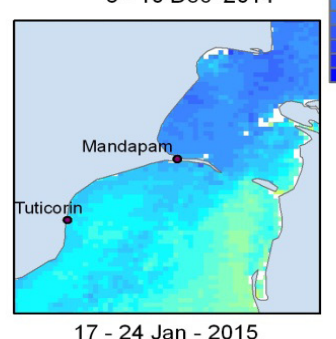

17 - 24 Jan - 2015

Fig.10: SST Map of Gulf of Mannar and Palk bay during September 2014 to January 2015

MODIS L3 Sea Surface Temperature Map of Mandapam region Jan 2015 to Mar 2015

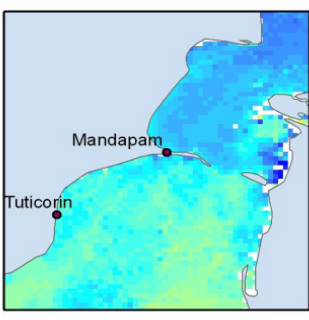

25 Jan - 1 Feb 2015

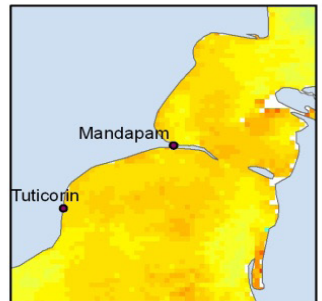

26 Feb - 5 Mar, 2015

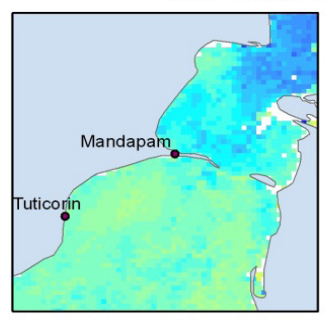

2 - 9 Feb 2015

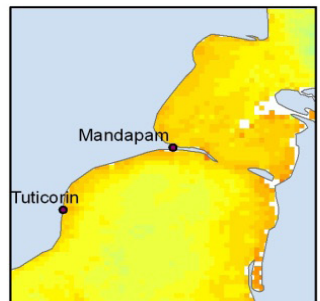

6 - 13 Mar, 2015

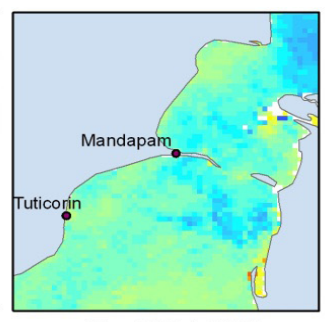

$10-17$ Feb 2015

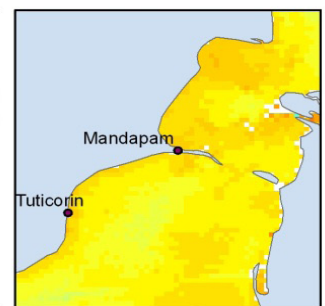

14 - 21 Mar, 2015
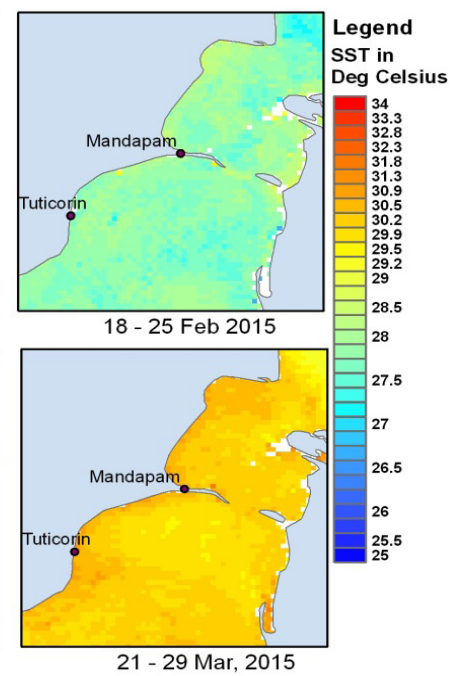

Fig. 11: SST Map of Gulf of Mannar and Palk bay during January 2015 to March 2015 


\section{MODIS L3 Sea Surface Temperature Map of Mandapam region Apr 2015 to May 2015}

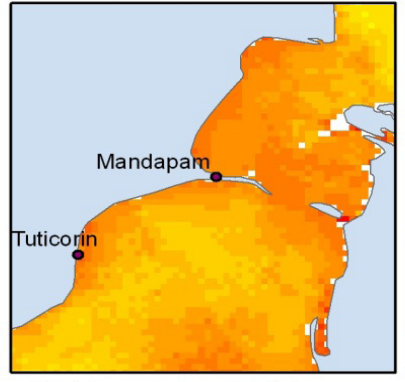

30 Mar - 6 Apr, 2015

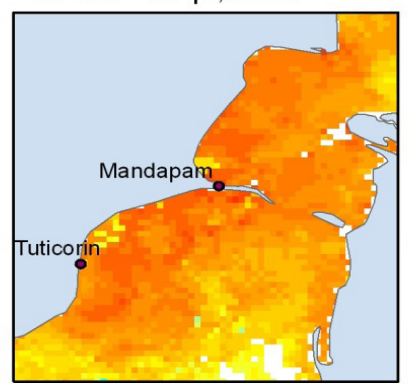

1 - 8 May, 2015

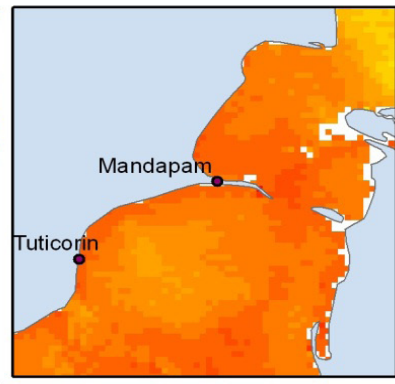

7 - 14 Apr, 2015

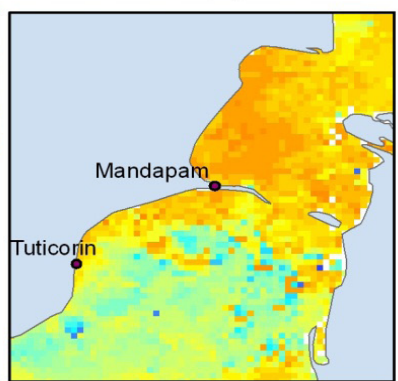

17 - 24 May, 2015

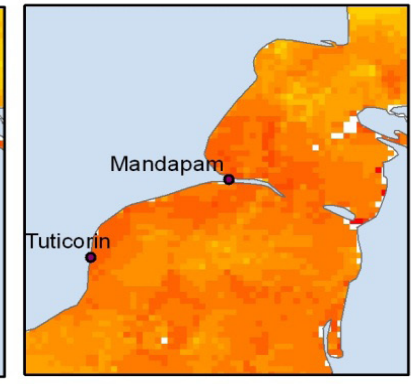

23 - 30 Apr, 2015

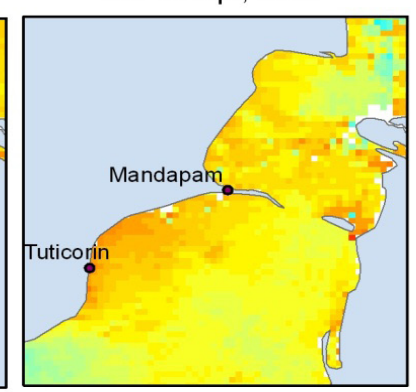

25 May - 1 June, 2015
Legend SST in Deg Celsius

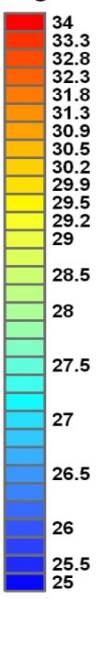

Fig.12: SST Map of Gulf of Mannar and Palk bay during March 2015 to May 2015 period was collected from the http://www.sunriseand-sunset.com/ for the study period from October 2013 to May 2015. The correlation between monthly mean GSI with Photoperiod and effect of sea surface temperature(SST) on mean GSI was assessed by calculating Pearson Correlation coefficient for the sea urchin, T. toreumaticus. All statistical analysis was performed using SPSS V.20.

\section{RESULTS AND DISCUSSION}

The analysis indicated that the strength of the association between SST and Mean monthly gonad index was negative $(r=-0.319)$ and the $p$ value was $(<0.001)$ (Table.1). Similarly the correlation between photoperiod and mean monthly gonad index was also negative $(r=-0.400)$ and the $p$ value was $(p<0.001)$ (Table.2). This result clearly shows that any increase or decrease in the two abiotic factor viz., SST and Photoperiod would invariably influence the gonadal development process of this sea urchin species in the Gulf of Mannar. A major peak of gonadosomatic index was observed inthe population of Temnopleurus toreumaticus, from the
Gulf of Mannar during December -2013 and October -2014 , followed by a spawning period. (Fig. 1\&2)

The Gulf of Mannar is calm during April to September and experiences both the monsoon. The environmental conditions, especially temperature and photoperiod, and the food availability influence the gamete maturation and spawning of marine invertebrates (Pearse and Cameron, 1991). Analysis of SST data from Gulf of Mannar clearly showed a winter cooling of surface water to a level of 4 degree variation between summer and winter (Fig. 3-12). Temperature also can affect spawning duration and thus act directly on the gonad growth and nutrient accumulation that allow gametogenesis. Sea water temperature appears to be an important controlling factor for the onset and duration of the breeding period (Soualili and Guillou, 2009). Vaitilingon et al. (2005) observed that the gonad index was negatively correlated to temperature and day length, indicating that higher values of GI were noted when temperature and day length were low in the sea urchin Tripneustes gratilla from Madagascar. Byrne et al. (1981) reported that the sea urchin species 
Centrostephanus rodgersii, a temperate sea urchin species coincide its gonadal maximum development with the increase of photoperiod. Shpigel et al. (2004) presented evidence that temperatures of $18-22^{\circ} \mathrm{C}$ enhanced gonad growth in $P$. lividus but that gametogenesis was controlled by photoperiod: long days reduced rates of gametogenesis and short days increased reproductive development. But in present investigation the sea urchin T.toreumaticusis strongly influenced by both SST and photoperiod. The results of the present study on the influence of abiotic parameters SST and Photoperiod on the gonadal development showed that the influence is greater and other nutritional factors in the Gulf of Mannar ecosystem may play a pivotal role in the reproduction and gonadal maturation in the sea urchin species Temnopleurus toreumaticus.

\section{ACKNOWLEDGEMENT}

The authors are thankful to the encouragement and support given by the Director of Central Marine Fisheries Research Institute and Dean of Fisheries College and Research Institute, towards this work.

\section{REFERENCES}

1. Muthiga, N.A., and Jaccarini, V. Effects of seasonality and population density on the reproduction of the Indo-Pacific echinoid Echinometra mathaei in Kenyan coral reef lagoons. Marine Biology,146:445453(2005). http://dx.doi.org/10.1007/s00227004-1449-9

2. Vaitilingon, D., Rasolofonirina, R., andJangoux, M. Reproductive cycle of edible echinoderms from the southwestern Indian Ocean I Tripneustes gratilla L. (Echinoidea, Echinodermata). WesternIndian Ocean Journal of Marine Science, 4:47-60 (2005)

3. Moore, H.B. A comparison of the biology of Echinus esculentus in different habitats. Part I. Journal of Marine Biological Association of UK, 19: 869- 885 (1934). http://dx.doi. org/10.1017/S002531540004683X

4. Wangensteen, O.S., Turon, X., Casso, M., and Palacin,C. The reproductive cycle of the sea urchin Arbacia lixula in northwest Mediterranean: potential influence of temperature and photoperiod. Marine Biology, 160:3157-3168 (2013). http://dx.doi. org/10.1007/s00227-013-2303-8
5. Pearse, J.S., and Cameron, R.A. Echinodermata: Echinoidea. In: Giese, A.C., Pearse, J.S., andPearse, V.B. (Eds) Reproduction of marine invertebrates, Volume VI Echinoderms and Lophophorates. The Boxwood Press, California. 513-662 (1991)

6. Soualili, D., and Guillou, M. Variation in the reproductive cycle of the sea urchin Paracentrotus lividus in three differently polluted locations near Algiers (Algeria). Marine Biodiversity Records, 2, e100 doi: 10.1017/S175526720900092X. (2009)

7. Byrne, M., Andrew, N.L., Worthington, D.G., andBrett, P.A. Reproduction in the diadematoid sea urchin Centrostephanus rodgersii in contrasting habitats along the coast of NewSouthWales,Australia. Marine Biology, 132: 305-318 (1998). http://dx.doi. org/10.1007/s002270050396

8. Shpigel, M., McBride, S.C., Marciano, S., Lupatsch, I. The effect of photoperiod and temperature on the reproduction of European sea urchin Paracentrotus lividus. Aquaculture, 232: 343-355(2004). http://dx.doi.org/10.1016/ S0044-8486 (03)00539-8 